\title{
Chapter 3 \\ Observed and Projected Impacts \\ from Extreme Weather Events: \\ Implications for Loss and Damage
}

\author{
Laurens M. Bouwer
}

\begin{abstract}
This chapter presents current knowledge of observed and projected impacts from extreme weather events, based on recorded events and their losses, as well as studies that project future impacts from anthropogenic climate change. The attribution of past changes in such impacts focuses on the three key drivers: changes in extreme weather hazards that can be due to natural climate variability and anthropogenic climate change, changes in exposure and vulnerability, and risk reduction efforts. The chapter builds on previous assessments of attribution of extreme weather events, to drivers of changes in weather hazard, exposure and vulnerability. Most records of losses from extreme weather consist of information on monetary losses, while several other types of impacts are underrepresented, complicating the assessment of losses and damages. Studies into drivers of losses from extreme weather show that increasing exposure is the most important driver through increasing population and capital assets. Residual losses (after risk reduction and adaptation) from extreme weather have not yet been attributed to anthropogenic climate change. For the Loss and Damage debate, this implies that overall it will remain difficult to attribute this type of losses to greenhouse gas emissions. For the future, anthropogenic climate change is projected to become more important for driving future weather losses upward. However, drivers of exposure and especially changes in vulnerability will interplay. Exposure will continue to lead to risk increases. Vulnerability on the other hand may be further reduced through disaster risk reduction and adaptation. This would reduce additional losses and damages from extreme weather. Yet, at the country scale and particularly in developing countries, there is ample evidence of increasing risk, which calls for significant improvement in climate risk management efforts.
\end{abstract}

Keywords Extreme weather $\cdot$ Flood $\cdot$ Storm $\cdot$ Losses $\cdot$ Risk $\cdot$ Normalisation Attribution

\author{
L. M. Bouwer $(\bowtie)$ \\ Climate Service Center Germany (GERICS), Hamburg, Germany \\ e-mail: laurens.bouwer@hzg.de
}

L. M. Bouwer

Deltares, Delft, The Netherlands

(C) The Author(s) 2019

R. Mechler et al. (eds.), Loss and Damage from Climate Change, Climate Risk

Management, Policy and Governance, https://doi.org/10.1007/978-3-319-72026-5_3 


\subsection{Introduction}

\subsubsection{Impacts from Extreme Weather}

Impacts from anthropogenic climate change are often equated with impacts from weather-related natural hazards, such as floods, droughts and windstorms. Extreme weather events can lead to substantial impacts, including loss of life, damages to buildings, agricultural production and natural capital, as well as longer term economic effects. The discussion on Loss and Damage from climate change therefore warrants a discussion on the extent to which increases in impacts from extreme weather have already occurred, what impacts can be expected in the future, and which losses cannot be prevented or reduced through risk reduction and adaptation.

In this chapter "climate change" is defined according to the definition by the Intergovernmental Panel (IPCC 2012), which includes both natural variability, as well as human induced climate change from anthropogenic forcing such as greenhouse gas emissions. Losses and damages have varying definitions, and we discuss these in the light of current understanding of impacts from weather extremes. As explained in the introductory chapter (Mechler et al. 2018), "losses" refer to monetary losses, while "damages" are meant to cover non-monetary impacts as well as irreversible effects. Losses from extreme weather can include both types; monetary losses (damages to buildings and other property that can be repaired or replaced), as well non-monetary impacts such as loss of life, health impacts, and irreversible damages such as coastal erosion, ecosystem impacts and societal impacts (for instance retreat after severe flooding).

Current understanding shows that the changes in impacts from extreme weather hazards are largely moderated by the extent to which humans and assets are exposed to these hazards, and to what extent they are vulnerable or sensitive to these hazards. This implies that apart from the actual occurrence of the hazards, the level of impacts - relevant to the Loss and Damage debate - is influenced by non-climatic factors. Quantitative risk assessment methods and approaches practiced since many decades in natural hazard research can help to assess risk from weather and geophysical extremes using the combination of these processes. The framework that combines these elements of hazard, exposure, and vulnerability as developed by the IPCC (2012) has now become widely accepted by the climate change research community to understand and study the occurrence as well as temporal changes in the impacts from extremes (e.g. Huggel et al. 2013; see framework depicted in Fig. 3.1).

The hazard driver is influenced by changes in climate; both from anthropogenic climate change, resulting from greenhouse gas emissions, as well as natural climate variability. Exposure is influenced by changes in development, including population growth and economic development that lead to increased accumulation of people and capital assets in locations that are at risk from natural hazards. Vulnerability and exposure may change because of adaptation and risk reduction actions that increase the protection from weather hazards and reduce sensitivity to these extremes that would otherwise results in negative impacts. Governance can influence land-use 


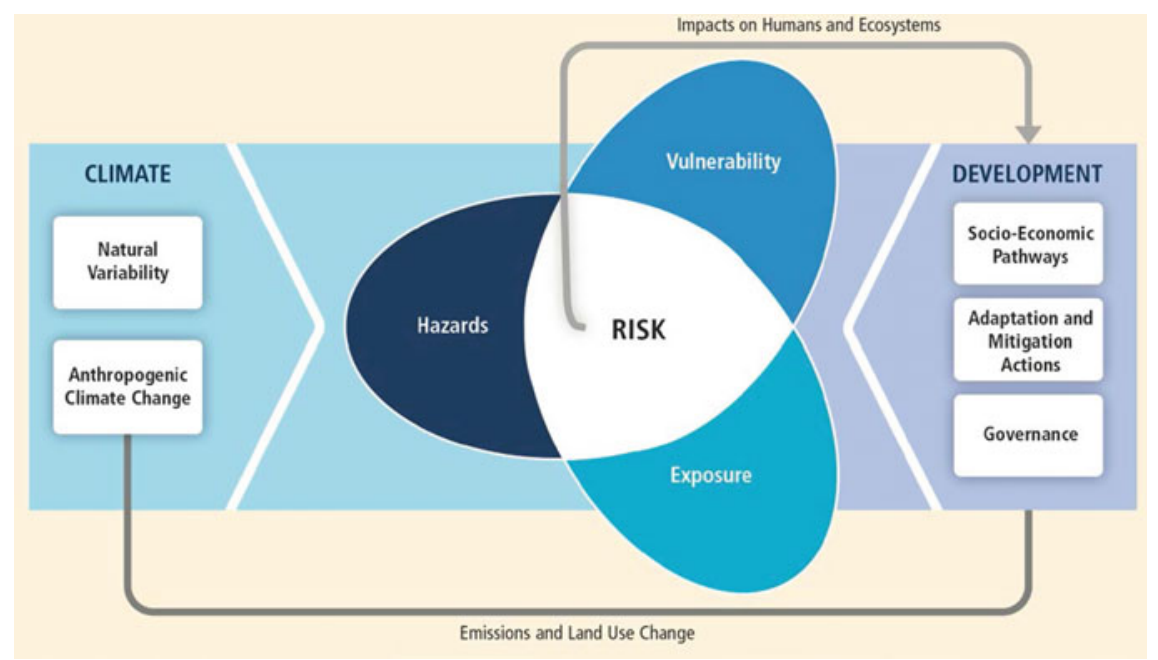

Fig. 3.1 Risk framework for the analysis of extreme event impacts. Source IPCC (2012)

planning that helps to reduce exposure, as well as the absorption of losses through risk transfer such as insurance, thereby changing vulnerability.

\subsubsection{Extreme Weather Impacts and Loss and Damage}

Impacts from anthropogenic climate change are manifold, and there are mostly negative consequences, especially with higher rates of warming, as well as a few positive effects. Here we focus on the impacts from extreme weather events. This provides only a partial picture of Loss and Damage, as there may be negative consequences from climate change that are not related to extreme weather events. Such impacts occur because of more gradual shifts, often called slow-onset processes, in climate variables such as average (seasonal) land-surface temperatures, average rainfall, as well as other variables, such as sea-level rise, loss of ice and snow-cover, and increasing temperatures of water bodies such as rivers, lakes and oceans. These impacts include shifts or loss of ecosystems and biodiversity, coastal erosion and loss of land, submergence of low-lying islands and atolls, changes in agricultural yield, and loss of indigenous and cultural practices and traditions. Many of such impacts are treated in this book in the chapters by Serdeczny (2018) and van der Geest et al. (2018).

Still, a considerable share of impacts on natural and human systems is associated with changes in weather extremes as a result of natural climate variability, and possibly also anthropogenic climate change. An advantage for research is that impacts from extreme weather events are relatively well-documented across the globe, compared 
to impacts such from slow-onset events. Information on extreme weather impacts is available in observation databases on past disasters collected by humanitarian and development organisations and research institutes. Also, records of monetary losses from extreme weather are collected by the insurance and reinsurance industry. In the disasters and climate research community, the patterns and trends in these databases have been studied extensively, and therefore several analyses are available in the academic literature on observed impacts for many locations around the world, and these analyses are discussed in this chapter.

With regard to climate losses and damages, the question is whether the records of observed disaster losses are fit for the purpose of comprehensive monitoring and analysing losses and damages from climate change. Gall (2015) provides a critical review in this respect, and concluded that the scope of these databases needs to be broadened, in particular with respect to slow-onset events, and include other impacts besides direct economic losses, such as indirect impacts and losses. While not exhaustive, the disaster loss records provide at this moment the best opportunity to assess and monitor changes in socioeconomic impacts, at least for extreme weather and climate change.

In addition, many studies have projected future changes in risk from extreme weather events, for the purpose of disaster risk reduction planning and climate adaptation. These studies also take into account future changes in hazard, exposure and vulnerability, on the basis of physical modelling and scenarios (Bouwer 2013), and therefore serve to indicate what impacts are expected for the near and more distant future, that could inform Loss and Damage discussions.

As shown in other chapters such as the contribution by James et al. (2018), wider definitions and viewpoints on Loss and Damage can include the impacts from presentday climate, so without much influence of climate change. This implies that losses and damages could also include impacts from extreme weather that are not attributable to anthropogenic climate change, but simply to (baseline) risk that occurs because of occurrence of extreme weather. This risk has occurred always, regardless of climate change, or occurs because of natural variability or increased exposure of people and capital. In this context, understanding present-day risks from extreme weather, and understanding the role of drivers of changes in that risk, is important for discussions on Loss and Damage. These drivers and the way they are understood to determine risk, ultimately also determine the scope of losses and damages from these extreme events.

There seems to be some agreement that the Loss and Damage debate refers to residual impacts, i.e. after adaptation ("losses beyond adaptation") (see James et al. 2018). Also, losses and damages can refer to actual impacts that have already occurred, as well as potential future risks of further impacts and damages (see introduction by Mechler et al. 2018).

In this context, all drivers of weather related risks should be considered. This is because non-climatic drivers of risk (influencing exposure, and vulnerability) may consciously (through adaptation) or unconsciously be influenced, as for instance with increasing development and wealthy societies become better protected from extreme weather hazards. 
This chapter builds on previous major reviews of changes in past extreme weather events and their impacts, including the relevant summaries contained in IPCC reports, such as the Special Report on Managing the Risks of Extreme Events and Disasters to Advance Climate Change Adaptation (IPCC SREX; IPCC 2012), as well as the Fifth Assessment Report (IPCC 2013, 2014), and extends these with recent published studies. In addition, it provides a discussion of expectations of future losses under projected climate change. The discussion is complementary to other chapters that focus on the attribution of anthropogenic climate change (chapter by James et al. 2018), and decision making in the context of Loss and Damage (chapter by Lopez et al. 2018) as well as on risk management in the chapter by Botzen et al. (2018). The following topics are covered

- Observed changes in weather extremes and their relation with anthropogenic climate change;

- Observed changes in impacts from extreme weather, and their relation to changing weather extremes;

- Observed changes in exposure and vulnerability, leading to altered impacts from extreme weather;

- Possible changes in the future in terms of extreme weather impacts and losses and damages, based on projections from quantitative impact studies.

\subsection{Observed Changes in Weather Extremes}

The occurrence of weather extremes has been studied extensively, both in natural hazard research for the purpose of hazard probability estimation and design of protection, as well as in climate change research. At the same time, uncertainties in the attribution of extremes (such as windstorms) to anthropogenic climate change are larger than for slow-onset processes (such as annual average temperature change and sea-level rise) (IPCC 2013). This is partly because of the rare nature of extremes, which are often analysed at return periods of 100 years or more, and also because they often occur at spatial scales that are smaller than slow-onset events. For instance, tropical cyclones occur over smaller areas than major heat-wave or drought events. However, over recent years the attention to extreme weather events has increased, and possibilities to analyse and model the occurrence and intensity of these events have improved. For a number of extreme weather events, there is considerable evidence that these have increased in frequency and for some that anthropogenic emissions of greenhouse gases are a major cause of this increase.

Table 3.1 provides an overview of past changes in weather extremes and the role of anthropogenic forcing, as assessed by the IPCC in the SREX (IPCC 2012) and the Working Group I volume of the Fifth Assessment Report (IPCC 2013). From this table it can be concluded that the detection of changes and attribution to anthropogenic emissions has been established for extremes related to temperature and sea-level rise. 
Table 3.1 Observed changes in weather extremes and attribution to human greenhouse gas emissions

\begin{tabular}{|c|c|c|}
\hline Weather extreme & Observed past changes & Human contribution \\
\hline $\begin{array}{l}\text { Warmer (and/or fewer cold) } \\
\text { days and nights }{ }^{\mathrm{a}}\end{array}$ & $\begin{array}{l}\text { - Very likely increase } \\
\text { (decrease) in frequency over } \\
\text { most land areas }\end{array}$ & - Very likely \\
\hline Heat waves ${ }^{\mathrm{a}}$ & $\begin{array}{l}\text { - Medium confidence in } \\
\text { increase on global scale } \\
\text { - Likely increase in large } \\
\text { parts of Europe, Asia and } \\
\text { Australia }\end{array}$ & - Likely \\
\hline Heavy precipitation $^{\mathrm{a}}$ & $\begin{array}{l}\text { - Likely increases over more } \\
\text { land areas than decreases }\end{array}$ & - Medium confidence \\
\hline River floods ${ }^{\mathrm{b}}$ & $\begin{array}{l}\text { - Limited to medium } \\
\text { evidence for changes in } \\
\text { frequency of river floods at } \\
\text { the regional level } \\
\text { - Low confidence for sign of } \\
\text { change of river floods at the } \\
\text { global level }\end{array}$ & - \\
\hline Drought $^{\mathrm{a}}$ & $\begin{array}{l}\text { - Low confidence in change } \\
\text { on a global level } \\
\text { - Likely changes in some } \\
\text { regions (increase in } \\
\text { Mediterranean and West } \\
\text { Africa; decreases in central } \\
\text { North America and } \\
\text { north-west Australia) }\end{array}$ & - Low confidence \\
\hline Tropical cyclones ${ }^{\mathrm{a}}$ & $\begin{array}{l}\text { - Low confidence in increase } \\
\text { in activity (intensity and } \\
\text { frequency) on timescales of } \\
100 \text { years } \\
\text { - Virtually certain in North } \\
\text { Atlantic since } 1970\end{array}$ & - Low confidence \\
\hline Extra-tropical cyclones ${ }^{b}$ & $\begin{array}{l}\text { - Likely pole-ward shift of } \\
\text { storm tracks on the northern } \\
\text { and southern hemispheres }\end{array}$ & - \\
\hline Extreme sea-levels ${ }^{\mathrm{a}}$ & - Likely increase since 1970 & - Likely \\
\hline
\end{tabular}

Note Based on SREX and Fifth Assessment Report WGI reports from the IPCC $(2012,2013)$. For definition of confidence levels see IPCC (2013)

${ }^{\mathrm{a}}$ IPCC (2013) (Summary for Policymakers). ${ }^{\mathrm{b}}$ IPCC (2012) (Summary for Policymakers) 
For rainfall related extremes, including droughts and river flooding, findings regarding the detection of changes is more mixed, as is the attribution of these changes to human greenhouse gas emissions. For windstorms, in the tropical and extra-tropical regions, both the changes and the precise human contribution to these changes are even more uncertain. In addition, there is an extensive literature that has looked at how the likelihood of individual extreme weather events has possibly changed due to anthropogenic forcing (see James et al. 2018). In addition to monotonic changes from anthropogenic forcing, the role of natural variability in shaping the impacts from natural disasters can be very large. This is an important reason why even when trends in extremes are found, related to large decadal variability in the occurrence of extremes related to natural variability, the attribution of smaller changes over time to anthropogenic emissions. This is for instance the case for tropical cyclones, where large natural variability complicates the detection of any remaining trend (Knutson et al. 2010).

\subsection{Observed Impacts Based on Disaster Loss Records}

\subsubsection{Loss Data and Normalisation}

Several records are available of disaster losses. The most notable global databases consist of those managed by CRED (EM-DAT database, ${ }^{1}$ Munich Reinsurance Company (NatCatSERVICE database), ${ }^{2}$ and Swiss Reinsurance Company (SIGMA database). ${ }^{3}$ Besides these global databases, several combined are available under Desinventar. ${ }^{4}$ While these databases provide a good overall understanding of loss frequency and trends, several other records of natural hazard impacts exist that are more detailed, including national accounts of disaster losses and national and local insurance records. Some of these are also assessed in the studies reported here.

Several researchers have analysed disaster loss records, to assess the frequency and size of impacts from these hazards. In addition, many have analysed which drivers (hazard, exposure, or vulnerability) may have led to changes in these impacts over time. An often-used approach is so-called normalisation, which tries to account for changes in exposure over time, by applying correction factors to the observed loss record. These factors are based on the total size of the exposed assets and their value (see Pielke and Landsea 1998). This is also common practise in the insurance industry in order to arrive at a common reference baseline of historical loss events that can be compared to catastrophe models that simulate risks for today's exposure and vulnerabilities or for a specific baseline year (Pielke et al. 1999). Many

\footnotetext{
${ }^{1}$ http://www.emdat.be.

${ }^{2}$ https://www.munichre.com/en/reinsurance/business/non-life/natcatservice/index.html.

${ }^{3}$ http://institute.swissre.com/research/overview/sigma_data/.

${ }^{4}$ https://www.desinventar.org/ and http://www.desinventar.net/.
} 
of the studies that applied loss normalisation also refer to "attribution of changes in impacts." This is however different from the formal detection and attribution as approached by the climate research community, which usually refers to the detection ${ }^{5}$ of statistically significant changes in climate variables, and attribution ${ }^{6}$ of these changes to natural forcing and anthropogenic greenhouse gas emissions. In the case of studies on disaster losses, attribution takes two steps: first attribution of the observed change in disaster losses to socioeconomic drivers (exposure, vulnerability), and next establish whether there is a remaining trend, that could be attributed to changing weather hazard conditions, usually regardless of human causes (e.g. Huggel et al. 2013). Other lines of research, include so-called event attribution studies put a direct link between the occurrence of individual extreme events and increased likelihood of these events that is due to anthropogenic forcing. In a few cases, also the impacts or losses from these events are included in the models (e.g. Pall et al. 2011), but not changes in other variables beside climate, such as changes in catchment hydrology or flood defences that would also influence flood risk (Schaller et al. 2016). These event attribution studies are further discussed in the chapter by James et al. (2018).

\subsubsection{Analysis of Loss Trends}

A number of assessments is available of the current understanding of disaster loss records on the basis of individual studies, most notably the IPCC SREX report (IPCC 2012), including the chapter on human and ecosystem impacts by Handmer et al. (2012), and in the contribution from Working Group II to the Fifth Assessment report, including the chapters on attribution by Cramer et al. (2014), and on the insurance sector in the chapter by Arent et al. (2014). Throughout these chapters, it is acknowledged that losses from natural hazards have increased, regardless of causation of the increase. In addition, it is noted that losses from weather-related hazards have increased more rapidly than from geophysical events such as earthquakes (e.g. Handmer et al. 2012). The assessments of IPCC have concluded the following on the causes of the upward trends in losses from extreme weather events:

Long-term trends in economic disaster losses adjusted for wealth and population increases have not been attributed to climate change, but a role for climate change has not been excluded (SREX SPM, IPCC 2012).

Economic losses due to extreme weather events have increased globally, mostly due to increase in wealth and exposure, with a possible influence of climate change (Cramer et al. 2014).

\footnotetext{
${ }^{5}$ Detection: "Detection of change is defined as the process of demonstrating that climate or a system affected by climate has changed in some defined statistical sense, without providing a reason for that change" (IPCC 2013: Annex III Glossary).

${ }^{6}$ Attribution: "Attribution is defined as the process of evaluating the relative contributions of multiple causal factors to a change or event with an assignment of statistical confidence" (IPCC 2013: Annex III Glossary).
} 
In sum, while increasing trends are found for losses from past extreme weather events, increasing exposure has been the main driver, and climate change (both anthropogenic climate change as well as natural climate variability) could have an additional role, but this role was not substantiated. The confidence of the role of anthropogenic climate change as driver in the upward trend in disaster loses is however low. Results from these previous reviews, as well as more recent studies on disaster loss databases, are displayed in Table 3.2. In total 34 studies are included. Most of these studies have analysed monetised losses from extreme weather events, although in some cases the losses concern quantified impacts, such as volume of damaged timber wood. And most studies account for increasing exposure, using either data on exposed capital assets, population, wealth indicators, and an inflation correction.

While this overview is perhaps neither exhaustive nor complete, it provides a comprehensive overview of scientific studies on impacts from major extreme weather types, such as tropical and extra-tropical cyclones, rainfall flooding, hailstorms, wildfires and convective weather types. While coastal flooding is often included in tropical cyclone losses, drought events are underrepresented in these studies. A few studies detect trends at the regional or national level, the overall conclusion is that very few upward trends are found, after normalising for changes in exposure.

There are several issues related to the normalisation approach, as well as the interpretation of normalised losses. First of all, the general assumption is that the change in the major driver of losses, that is increasing exposure of assets, has a proportional (linear) relation with the losses (e.g. Pielke and Landsea 1998; Bouwer 2011a; Handmer et al. 2012). But alternative approaches such as from Estrada et al. (2015) show that alternative formulations of statistical models with explanatory variables may lead to different trends in losses, such as for US hurricanes. Such approaches are however not yet conclusive, and need further confirmation in consecutive studies (Hallegatte 2015).

In addition, the interpretation of the normalised record is also not straightforward. As Visser et al. (2014) and Visser and Petersen (2012) show, different statistical methods for trend detection may lead to different interpretation of upward, downward or no trends found in the normalised loss records of extreme weather events. And how fluctuations in the normalised loss-record are interpreted, possibly related to natural climate variability, is another matter of discussion.

What is clear from the normalisation studies listed here (Table 3.2) is that most do not find an increasing trend in losses, after the records have been normalised for increasing exposure. This implies that the main driver of the observed losses likely has been an increasing number of population and assets, and not a change in the hazard frequency or severity. A few studies however do find increases in losses, also after normalisation. These include most notably convective weather events, including thunderstorms and hailstorms, where three studies find increasing trends for over several decades. With increasing temperatures, there is a possibility that extremes related to convective weather could become more frequent. However, IPCC (2012) 
Table 3.2 Normalisation studies of weather-related disaster loss records

\begin{tabular}{|c|c|c|c|c|}
\hline Hazard & Location & Period & Normalised loss & References \\
\hline \multicolumn{5}{|c|}{ Tropical cyclones (9 studies) } \\
\hline Tropical storm & Latin America & 1944-1999 & No trend & Pielke et al. (2003) \\
\hline Tropical storm & India & $1977-1998$ & No trend & $\begin{array}{l}\text { Raghavan and } \\
\text { Rajesh (2003) }\end{array}$ \\
\hline Tropical storm & USA & 1900-2005 & No trend & Pielke et al. (2008) \\
\hline Tropical storm & USA & 1950-2005 & $\begin{array}{l}\text { Increase since } \\
1970 ; \text { no trend } \\
\text { since } 1950\end{array}$ & $\begin{array}{l}\text { Schmidt et al. } \\
\text { (2009) }\end{array}$ \\
\hline Tropical storm & China & $1983-2006$ & No trend & Zhang et al. (2009) \\
\hline Tropical storm & USA & $1900-2008$ & Increase since 1900 & Nordhaus (2010) \\
\hline Tropical storm & USA & 1900-2005 & No trend & $\begin{array}{l}\text { Bouwer and Botzen } \\
\text { (2010) }\end{array}$ \\
\hline Tropical storm & USA & $1900-2005$ & Increase since 1900 & Estrada et al. (2015) \\
\hline Tropical storm & China & $1984-2013$ & No trend & Fischer et al. (2015) \\
\hline \multicolumn{5}{|c|}{ Extra-tropical cyclones (3 studies) } \\
\hline Windstorm & USA & $1952-2006$ & Increase since 1952 & Changnon (2009b) \\
\hline Windstorm & Europe & $1970-2008$ & No trend & Barredo (2010) \\
\hline Windstorm & Switzerland & $1859-2011$ & No trend & Stucki et al. (2014) \\
\hline \multicolumn{5}{|c|}{ Snow storms (1 study) } \\
\hline $\begin{array}{l}\text { Ice, blizzard and } \\
\text { snow storms }\end{array}$ & USA & $1949-2003$ & Increase since 1949 & Changnon (2007) \\
\hline \multicolumn{5}{|c|}{ Convective weather (7 studies) } \\
\hline Thunderstorm & USA & $1949-1998$ & Increase since 1974 & Changnon (2001) \\
\hline Tornado & USA & 1890-1999 & No trend & $\begin{array}{l}\text { Brooks and } \\
\text { Doswell (2001) }\end{array}$ \\
\hline Tornado & USA & $1900-2000$ & No trend & Boruff et al. (2003) \\
\hline Hailstorm & USA & $1951-2006$ & Increase since 1992 & Changnon (2009a) \\
\hline Hailstorm & $\begin{array}{l}\text { Southwest } \\
\text { Germany }\end{array}$ & 1974-2003 & $\begin{array}{l}\text { Increase over last } \\
20 \text { years }\end{array}$ & Kunz et al. (2009) \\
\hline Tornado & USA & 1950-2011 & No trend & $\begin{array}{l}\text { Simmons et al. } \\
(2013)\end{array}$ \\
\hline Thunderstorm & USA & 1970-2009 & $\begin{array}{l}\text { Increasing trend } \\
\text { since } 1990\end{array}$ & Sander et al. (2013) \\
\hline \multicolumn{5}{|c|}{ Flooding (7 studies) } \\
\hline River flood & USA & $1926-2000$ & No trend & $\begin{array}{l}\text { Downton and } \\
\text { Pielke (2005) }\end{array}$ \\
\hline River flood & China & 1950-2001 & Increase since 1987 & $\begin{array}{l}\text { Fengqing et al. } \\
(2005)\end{array}$ \\
\hline
\end{tabular}


Table 3.2 (continued)

\begin{tabular}{|c|c|c|c|c|}
\hline Hazard & Location & Period & Normalised loss & References \\
\hline River flood & Europe & 1970-2006 & No trend & Barredo (2009) \\
\hline River flood & Korea & $1971-2005$ & Increase since 1971 & Chang et al. (2009) \\
\hline $\begin{array}{l}\text { River flood and } \\
\text { landslides }\end{array}$ & Switzerland & $1972-2007$ & No trend & Hilker et al. (2009) \\
\hline River flood & Spain & 1971-2008 & No trend & $\begin{array}{l}\text { Barredo et al. } \\
\text { (2012) }\end{array}$ \\
\hline River flooding & Spain & $1975-2013$ & No trend & $\begin{array}{l}\text { Pérez-Morales et al. } \\
\text { (2018) }\end{array}$ \\
\hline \multicolumn{5}{|l|}{ Wildfire (1 study) } \\
\hline Bushfire & Australia & $1925-2009$ & No trend & $\begin{array}{l}\text { Crompton et al. } \\
\text { (2010) }\end{array}$ \\
\hline \multicolumn{5}{|c|}{ Various weather (9 studies) } \\
\hline $\begin{array}{l}\text { Weather } \\
\text { (hurricanes, floods) }\end{array}$ & USA & 1951-1997 & No trend & $\begin{array}{l}\text { Choi and Fisher } \\
\text { (2003) }\end{array}$ \\
\hline $\begin{array}{l}\text { Weather (flood, } \\
\text { thunderstorm, hail, } \\
\text { bushfires) }\end{array}$ & Australia & 1967-2006 & No trend & $\begin{array}{l}\text { Crompton and } \\
\text { McAneney (2008) }\end{array}$ \\
\hline $\begin{array}{l}\text { Weather (hail, } \\
\text { storm, flood, } \\
\text { wildfire) }\end{array}$ & World & $1950-2005$ & $\begin{array}{l}\text { Increase since } \\
\text { 1970; no increase } \\
\text { since } 1950\end{array}$ & Miller et al. (2008) \\
\hline $\begin{array}{l}\text { Weather (floods, } \\
\text { convective events, } \\
\text { winter storms, } \\
\text { tropical cyclones, } \\
\text { heatwaves) }\end{array}$ & World & $1980-2008$ & No trend & $\begin{array}{l}\text { Neumayer and } \\
\text { Barthel (2011) }\end{array}$ \\
\hline $\begin{array}{l}\text { Weather (winter } \\
\text { storms, heatwaves) }\end{array}$ & Germany & 1980-2008 & Increase since 1980 & $\begin{array}{l}\text { Neumayer and } \\
\text { Barthel (2011) }\end{array}$ \\
\hline $\begin{array}{l}\text { Weather (floods, } \\
\text { convective events }\end{array}$ & Germany & 1980-2008 & No trend & $\begin{array}{l}\text { Neumayer and } \\
\text { Barthel (2011) }\end{array}$ \\
\hline $\begin{array}{l}\text { Weather (floods, } \\
\text { convective events, } \\
\text { winter storms, } \\
\text { tropical cyclones, } \\
\text { heatwaves) }\end{array}$ & USA & 1980-2008 & Increase since 1980 & $\begin{array}{l}\text { Neumayer and } \\
\text { Barthel (2011) }\end{array}$ \\
\hline $\begin{array}{l}\text { Natural disasters } \\
\text { (including extreme } \\
\text { temperatures, } \\
\text { floods, mass } \\
\text { movement, storms, } \\
\text { wildfire) }\end{array}$ & China & 1990-2011 & No trend & Zhou et al. (2013) \\
\hline $\begin{array}{l}\text { Weather (tropical } \\
\text { cyclones, flooding, } \\
\text { drought) }\end{array}$ & India (Odisha) & 1972-2009 & No trend & $\begin{array}{l}\text { Bahinipati and } \\
\text { Venkatachalam } \\
(2016)\end{array}$ \\
\hline
\end{tabular}

Updated from Bouwer (2011a), including Handmer et al. (2012), Cramer et al. (2014), Arent et al. (2014) and other recent publications 
noted that there is insufficient evidence ${ }^{7}$ to conclude that severe convective weather has already become more frequent.

Other weather hazards for which positive loss trends are found include studies on tropical storms. While Nordhaus (2010) found a positive trend for US hurricane losses after normalisation, Bouwer and Botzen (2011) found no trend using other loss records and alternative normalisation of the same events. The study by Estrada et al. (2015) used an alternative formulation, assuming a non-linear relation between changes in exposure and losses, which has not yet been confirmed by other studies, nor has there been a sufficient explanation for the cause of the remaining increase in losses (Hallegatte 2015). Schmidt et al. (2009) found an increasing trend in US hurricane losses after normalisation since 1970 , but this is likely due to natural variability (Bouwer 2011a); in this case the low frequency of landfalling hurricanes in the North Atlantic and Caribbean in the 1970s, and the subsequent increase in the 1990s and early 2000s. For river flooding some studies find increases after normalisation (Fengqing et al. 2005; Chang et al. 2009), but these are relatively short-lived, and it is unclear whether these increases are related to changes in flood hazard driven by natural variability or anthropogenic climate change.

Finally, there are some studies that indicate increasing losses after normalisation at the global level, for several types of weather extremes (Miller et al. 2008; Neumayer and Barthel 2011), but these trends are also over recent times (over 30 years or less), and here it is also unclear whether any related changes in hazard are driven by natural variability or anthropogenic climate change.

\subsubsection{Interpretation of Drivers of Losses}

As shown above, few studies find signals in losses beyond the driver of increasing exposure. Less is known about the role of vulnerability changes that potentially may play an important role. As societies become wealthier, they are likely to start to invest more in risk reduction and adaptation, thereby reducing impacts from weather related hazards. This may result in reduced losses over time. For normalisation studies, this may imply that accounting for increases in exposure only, would downplay the role of any other contributing factors, including anthropogenic climate change (Nicholls 2011). Indeed, there are studies that show that especially loss of life and also monetary losses have decreased, despite increasing exposure (Mechler and Bouwer 2015; Bahinipati and Patnaik 2015; Kreibich et al. 2017; Bouwer and Jonkman 2018). Jongman et al. (2015) for instance stress that despite the fact that total losses from river flooding have increased, fatalities and monetised losses as a share of population and GDP, have fallen over past decades. However, the question is how significant these changes in vulnerability are, compared to the very rapid increase in exposure (Bouwer 2011b). While loss of life clearly has benefitted from improved early

\footnotetext{
7"There is low confidence in observed trends in small spatial-scale phenomena such as tornadoes and hail because of data inhomogeneities and inadequacies in monitoring systems" (IPCC 2012:8).
} 
warning and evacuation, and vulnerability has substantially declined (Mechler and Bouwer 2015; Bouwer and Jonkman 2018), monetary losses can only be substantially prevented from improved protection, such as through flood prevention, improved building construction, and alternative agricultural practices. There are however very few longitudinal studies that have assessed these effects over sufficiently long periods over time, to establish the long-terms effects, compared to increasing exposure. The studies indicating substantial reductions in monetary losses have considered the most recent decades (Jongman et al. 2015; Kreibich et al. 2017), and while efforts may have been successful at improving the current situation, they can hardly make up for substantial development in vulnerable areas that has been taken place over the last 100 years.

Finally, for attributing changes in extreme weather impacts, in the context of Loss and Damage, any remaining trend after normalisation and after accounting for vulnerability reduction would need to be demonstrated to have a relation with changes in extreme weather hazards. And this change in extreme weather hazard in turn should be attributed to anthropogenic climate change. Table 3.3 summarises the results from the review of loss normalisation studies (Table 3.2), as well as the observed changes in weather extremes (Table 3.1). While for several weather extremes, increasing occurrence has been observed, and often also attributed to anthropogenic greenhouse gas forcing (Table 3.1), these changes are not reflected in loss records, or at least cannot be recognised. No substantial evidence is present for long-term increases in normalised losses from these types of extreme weather, based on quantified loss records. And while a few studies show that losses from convective weather may have increased, in particular losses from hail and thunderstorm events (Changnon 2001; Changnon 2009a; Kunz et al. 2009; Sander et al. 2013), these are yet to be linked to structural changes in the occurrence of convective weather events, related to greenhouse gas forcing (IPCC 2012, 2013).

Table 3.3 Comparison of changes in extreme weather hazards (regardless of human contribution) and observed change in losses

\begin{tabular}{l|l|l}
\hline Type & $\begin{array}{l}\text { Increase in extreme weather } \\
\text { hazard? }\end{array}$ & Increase in observed losses? \\
\hline Heat wave & Very likely & Unknown \\
\hline Heavy precipitation & Likely & Unknown \\
\hline River floods & Limited/medium evidence & No increase \\
\hline Drought & Low confidence & Unknown \\
\hline Tropical cyclones & Low confidence & No increase \\
\hline Extra-tropical cyclones & Likely poleward shift & No increase \\
\hline Extreme sea-levels & Likely & Unknown \\
\hline Wildfires & Unknown & No increase \\
\hline Convective weather & Unknown & Possible increase?
\end{tabular}




\subsection{Projections of Future Extreme Weather Losses}

As a stylised case, Fig. 3.2 provides an illustration of how past risk from extreme weather has increased, and how this risk can be reduced or avoided through disaster risk reduction (protection and prevention). There will always remain a residual risk (see also chapter by Schinko et al. 2018), which cannot be reduced in a cost-efficient way, i.e. the costs of eliminating the risk are considered higher than incurring the costs. However, current risk has increased by increasing exposure, and possibly by anthropogenic climate change. Part or all of this risk is related to the Loss and Damage debate, depending on whether or not residual impacts are considered to be included. Future risk will increase further due to anthropogenic climate change, leading to an increasing amount of losses and damages, not addressed by disaster risk reduction and adaptation. However, as vulnerability is likely to be further reduced (see also evidence discussed in Sect. 3.3), the share avoided by disaster risk reduction and adaptation will also increase. The losses and damages after adaptation include unavoidable losses and damages, potentially including the residual risks that will remain.

Various studies also project quantified future losses from extreme weather, mostly for risk assessment purposes in the context of vulnerability and adaptation studies at national or international level, and also for planning and design purposes at local level. These studies are assessed by several authors, including IPCC (e.g. Handmer et al. 2012; Arent et al. 2014). Overall, these studies recognise that changing weather hazards have a role, driven by anthropogenic climate change as major driver of

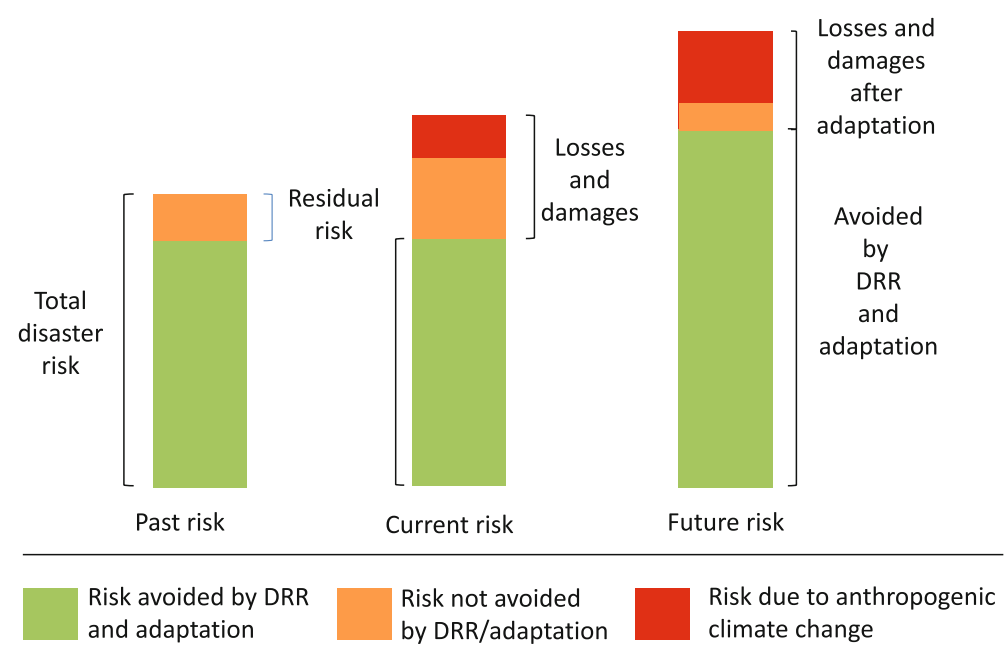

Fig. 3.2 Past, current and future risk from extreme weather events, and the relation to Loss and Damage 
risk. The hazards that are studied include tropical and extra-tropical cyclones, river flooding, coastal flooding, as well as small scale phenomena such as hailstorms.

Exposure and vulnerability are also considered as important drivers of future risks. Many but not all of these studies also integrate projections of increasing population and wealth or capital at risk in the quantitative estimates of future risk. A comparison of these estimates shows that for tropical cyclones and extra-tropical cyclones, the effects of future increases in exposure are much larger than from increasing hazard frequency as a consequence of anthropogenic climate change (Bouwer 2013). Some recent studies have analysed these signals together in a single analysis, such as Crompton et al. (2011). They show that for tropical cyclones in the USA, it will take at least until the end of this century before the effects from anthropogenic climate change can be disentangled from the loss record. Muis et al. (2016) show for Indonesia that coastal and river flood risk in the future will be largely driven by increasing exposure. Preston (2013) shows for various weather hazards in the USA that exposure potentially will have a major impact on losses until the year 2050 . Strader et al. (2017) show for tornado risk, that increasing expansion of urban areas in the US outweighs the effects of increasing severe weather occurrence.

Only very few studies have analysed the effects of a further decline in vulnerability, as a result of increasing risk reduction and adaption efforts, in comparison to projected future climate change. Jongman et al. (2015) shows that when considering vulnerability reduction (e.g., through adaptation and disaster risk reduction), future absolute losses from river flooding in terms of loss of life and monetary impacts could be substantially reduced, at the global scale than without adaptation, and under an optimistic scenario even declining, compared to today's risks. Also, Mechler and Bouwer (2015) show for Bangladesh that increases in risks are potentially lower when dynamic vulnerability is considered.

These projection studies imply that for Loss and Damage, it will remain difficult which elements of the actual losses from extreme weather are attributed to greenhouse gas emissions; first of all, increasing exposure could still play a dominant role. But in addition, successful vulnerability reduction could increasingly lead to a lowered pace of risk increases, compared to the past. Changes are observed in the frequency of several weather extremes, and anthropogenic climate change is an important driver for several of these. Also, losses, including monetary losses, from extreme weather events have increased, as can be seen from several observational records. The records of losses discussed above are focused on monetary losses, while several other types of impacts, including non-monetised damages and irreversible impacts from extreme weather, are underrepresented, complicating the assessment of losses and damages. Studies into drivers of losses from extreme weather show that increasing exposure has been the most important driver, through increasing population and capital assets. Anthropogenic climate change is currently not an important driver for changes in losses from events related to extreme wind, rainfall, and flooding, except perhaps for convective weather events (thunderstorms and hail). Other extreme weather types (such as extreme heat) have not been addressed in this chapter, and monetary losses are rarely assessed for extreme temperatures. It is known that anthropogenic climate change is increasing heatwave frequency, and mortality and morbidity have been high 
in recent events. Residual losses (after risk reduction and adaptation) from extreme weather have not yet been attributed to anthropogenic climate change. For the Loss and Damage debate, this implies that overall it is currently difficult to attribute losses to greenhouse gas emissions.

Anthropogenic climate change is projected to become more important for driving future weather losses upward. However, drivers of exposure and especially vulnerability reduction will interplay. Exposure will continue to lead to risk increases. Vulnerability on the other hand may to be further reduced if disaster risk reductionand adaptation is taken forward. As modelling studies show this would reduce losses and damages from extreme weather at the global scale. In the most optimistic scenario with high adaptation assumed, it could even reduce the burden from extreme weather. Yet, at national scales and particularly for developing countries there is ample evidence of increasing risk, which calls for a significant upgrade of climate risk management efforts.

\section{References}

Arent DJ, Tol RSJ, Faust E, Hella JP, Kumar S, Strzepek K, Tóth FL, Yan D (2014) Key economic sectors and services. In: Field CB, Barros VR, Dokken DJ, Mach KJ, Mastrandrea MD, Bilir TE, Chatterjee M, Ebi KL, Estrada YO, Genova RC, Girma B, Kissel ES, Levy AN, MacCracken S, Mastrandrea PR, White LL (eds) Climate change 2014: impacts, adaptation, and vulnerability. Part A: global and sectoral aspects. Contribution of working group II to the fifth assessment report of the intergovernmental panel of climate change. Cambridge University Press, Cambridge, United Kingdom and New York, NY, USA, pp 659-708

Bahinipati CS, Patnaik U (2015) The damages from climatic extremes in India: do disaster-specific and generic adaptation measures matter? Environ Econ Policy Stud 17:157-177

Bahinipati CS, Venkatachalam L (2016) Role of climate risks and socio-economic factors in influencing the impact of climatic extremes: a normalisation study in the context of Odisha, India. Reg Environ Change 16(1):177-188

Barredo JI (2009) Normalised flood losses in Europe: 1970-2006. Nat Hazards Earth Syst Sci 9:97-104

Barredo JI (2010) No upward trend in normalised windstorm losses in Europe: 1970-2008. Nat Hazards Earth Syst Sci 10:97-104

Barredo JI, Sauri D, Carmen-Llasat MC (2012) Assessing trends in insured losses from floods in Spain 1971-2008. Nat Hazards Earth Syst Sci 12:1723-1729

Boruff BJ, Easoz JA, Jones SD, Landry HR, Mitchem JD, Cutter SL (2003) Tornado hazards in the United States. Climate Res 24:103-117

Botzen W, Bouwer LM, Scussolini P, Kuik O, Haasnoot M, Lawrence J, Aerts JCJH (2018) Integrated disaster risk management and adaptation. In: Mechler R, Bouwer L, Schinko T, Surminski $\mathrm{S}$, Linnerooth-Bayer J (eds) Loss and damage from climate change. Concepts, methods and policy options. Springer, Cham, pp 287-315

Bouwer LM (2011a) Have disaster losses increased due to anthropogenic climate change? Bull Am Meteor Soc 92(1):39-46

Bouwer LM (2011b) Reply to comments on "Have disaster losses increased due to anthropogenic climate change?" Bull Am Meteorol Soc 92(6):792-793

Bouwer LM (2013) Projections of future extreme weather losses under changes in climate and exposure. Risk Anal 33(5):915-930 
Bouwer LM, Botzen WJW (2011) How sensitive are US hurricane damages to climate? Comment on a paper by W.D. Nordhaus. Clim Change Econ 1(2):1-7

Bouwer LM, Jonkman SN (2018) Global mortality from storm surges is decreasing. Environ Res Lett 13(1):014008

Brooks HE, Doswell CA (2001) Normalized damage from major tornadoes in the United States: 1890-1999. Weather Forecast 16:168-176

Chang H, Franczyk J, Kim C (2009) What is responsible for increasing flood risks? The case of Gangwon Province, Korea. Nat Hazards 48:339-354

Changnon SA (2001) Damaging thunderstorm activity in the United States. Bull Am Meteor Soc $82: 597-608$

Changnon SA (2007) Catastrophic winter storms: an escalating problem. Clim Change 84:131-139

Changnon SA (2009a) Increasing major hail losses in the U.S. Clim Change 96:161-166

Changnon SA (2009b) Temporal and spatial distributions of windstorm damages in the United States. Clim Change 94:473-483

Choi O, Fisher A (2003) The impacts of socioeconomic development and climate change on severe weather catastrophe losses: Mid-Atlantic region (MAR) and the U.S. Clim Change 58:149-170

Cramer W, Yohe G, Auffhammer M, Huggel C, Molau U, Da Silva Dias MAF, Solow A, Stone D, Tibig L (2014) Detection and attribution of observed impacts. In: Field CB, Barros VR, Dokken DJ, Mach KJ, Mastrandrea MD, Bilir TE, Chatterjee M, Ebi KL, Estrada YO, Genova RC, Girma B, Kissel ES, Levy AN, MacCracken S, Mastrandrea PR, White LL (eds) Climate change 2014: impacts, adaptation, and vulnerability. Part A: global and sectoral aspects, Chap 18. Contribution of working group II to the fifth assessment report of the intergovernmental panel of climate change. Cambridge University Press, Cambridge, United Kingdom and New York, NY, USA, pp 979-1037

Crompton RP, Pielke RA Jr, McAneney KJ (2011) Emergence time scales for detection of anthropogenic climate change in US tropical cyclone loss data. Environ Res Lett 6:014003

Crompton RP, McAneney KJ (2008) Normalised Australian insured losses from meteorological hazards: 1967-2006. Environ Sci Policy 11:371-378

Crompton RP, McAneney KJ, Chen K, Pielke RA Jr, Haynes K (2010) Influence of location, population, and climate on building damage and fatalities due to Australian bushfire: 1925-2009. Weather Clim Soc 2(10):300-310

Downton M, Pielke RA Jr (2005) How accurate are disaster loss data? The case of U.S. flood damage. Nat Hazards 35:211-228

Estrada F, Botzen WJW, Tol RSJ (2015) Economic losses from US hurricanes consistent with an influence from climate change. Nat Geosci 8:880-884

Fengqing J, Cheng Z, Guijin M, Ruji H, Qingxia M (2005) Magnification of flood disasters and its relation to regional precipitation and local human activities since the 1980s in Xinxiang, northwestern China. Nat Hazards 36:307-330

Fischer T, Su B, Wen S (2015) Spatio-temporal analysis of economic losses from tropical cyclones in affected provinces of China for the last 30 years (1984-2013). Nat Hazards Rev 16(4). https:// doi.org/10.1061/(ASCE)NH.1527-6996.0000186

Gall M (2015) The suitability of disaster loss data bases to measure loss and damage from climate change. Int J Global Warming 8(2):170-190

Hallegatte S (2015) Unattributed hurricane damage. Nat Geosci 8:819-820

Handmer J, Honda Y, Kundzewicz ZW, Arnell N, Benito Z, Hatfield J, Mohamed IF, Peduzzi P, Wu S, Sherstyukov B, Takahashi K, Yan Z (2012) Changes in impacts of climate extremes: human systems and ecosystems. In: Field CB, Barros V, Stocker TF, Qin D, Dokken DJ, Ebi KL, Mastrandrea MD, Mach KJ, Plattner G-K, Allen SK, Tignor M, Midgley PM (eds) Chapter 4. Cambridge University Press, USA, Cambridge, UK, and New York, NY, USpp 231-290

Hilker N, Badoux A, Hegg C (2009) The Swiss flood and landslide damage database 1972-2007. Nat Hazards Earth Sys Sci 9:913-925

Huggel C, Stone D, Auffhammer M, Hansen G (2013) Loss and damage attribution. Nat Clim Change 3(8):694-696 
IPCC (2012) Managing the risks of extreme events and disasters to advance climate change adaptation. A special report of working groups I and II of the intergovernmental panel on climate change. In: Field CB, Barros V, Stocker TF, Qin D, Dokken DJ, Ebi KL, Mastrandrea MD, Mach KJ, Plattner G-K, Allen SK, Tignor M, Midgley PM (eds). Cambridge University Press, USA, Cambridge, UK, and New York, NY, US, 582 pp

IPCC (2013) Climate change 2013: the physical science basis. Contribution of working group I to the fifth assessment report of the intergovernmental panel on climate change. In: Stocker TF, Qin D, Plattner G-K, Tignor M, Allen SK, Boschung J, Nauels A, Xia Y, Bex V, Midgley PM (eds). Cambridge University Press, Cambridge, United Kingdom and New York, NY, USA, 1535 pp

IPCC (2014) Climate change 2014: impacts, adaptation, and vulnerability. Part A: global and sectoral aspects. In: Field CB, Barros VR, Dokken DJ, Mach KJ, Mastrandrea MD, Bilir TE, Chatterjee M, Ebi KL, Estrada YO, Genova RC, Girma B, Kissel ES, Levy AN, MacCracken S, Mastrandrea PR, White LL (eds) Contribution of working group II to the fifth assessment report of the intergovernmental panel on climate change. Cambridge University Press, Cambridge, United Kingdom and New York, NY, USA, $1132 \mathrm{pp}$

James RA, Jones RG, Boyd E, Young HR, Otto FEL, Huggel C, Fuglestvedt JS (2018) Attribution: how is it relevant for loss and damage policy and practice? In: Mechler R, Bouwer L, Schinko T, Surminski S, Linnerooth-Bayer J (eds) Loss and damage from climate change. Concepts, methods and policy options. Springer, Cham, pp 113-154

Jongman B, Winsemius HC, Aerts JCJH, Coughlan de Perez E, Van Aalst MK, Kron W, Ward PJ (2015) Declining vulnerability to river floods and the global benefits of adaptation. Proc Natl Acad Sci USA 112(18):E2271-E2280

Knutson TR, McBride JL Chan J, Emanuel K, Holland G, Landsea C, Held I, Kossin JP, Srivastava AK, Sugi M (2010) Tropical cyclones and climate change. Nat Geosci 3:157-163

Kreibich H, Aerts JCJH, Apel H, Arnbjerg-Nielsen K, Di Baldassarre G, Bouwer LM, Bubeck P, Caloiero T, Cortés M, Do C, Gain AK, Giampá V, Kuhlicke C, Kundzewicz ZW, Llasat MC, Mård J, Matczak P, Mazzoleni M, Molinari D, Nguyen VD, Petrucci O, Schröter K, Slager K, Thieken AH, Vorogushyn S, Merz B (2017) Reducing flood risk by learning from past events. Earth's Future 5(10):953-965

Kunz K, Sander J, Kottmeier C (2009) Recent trends of thunderstorm and hailstorm frequency and their relation to atmospheric characteristics in southwest Germany. Int J Climatol 29:2283-2297

Lopez, A, Surminski S, Serdeczny O (2018) The role of the physical sciences in loss and damage decision-making. In: Mechler R, Bouwer L, Schinko T, Surminski S, Linnerooth-Bayer J (eds) Loss and damage from climate change. Concepts, methods and policy options. Springer, Cham, pp 261-285

Mechler R, Bouwer LM (2015) Understanding trends and projections of disaster losses and climate change: is vulnerability the missing link? Clim Change 133(1):23-35

Mechler R et al (2018) Science for loss and damage. Findings and propositions. In: Mechler R, Bouwer L, Schinko T, Surminski S, Linnerooth-Bayer J (eds) Loss and damage from climate change. Concepts, methods and policy options. Springer, Cham, pp 3-37

Miller S, Muir-Wood R, Boissonnade A (2008) An exploration of trends in normalized weatherrelated catastrophe losses. In: Diaz HF, Murnane RJ (eds) Climate extremes and society. Cambridge University Press, Cambridge, pp 225-347

Muis S, Verlaan M, Winsemius HC, Aerts JCJH, Ward PJ (2016) A global reanalysis of storm surges and extreme sea levels. Nat Commun 7:11969

Neumayer E, Barthel F (2011) Normalizing economic loss from natural disasters: a global analysis. Glob Environ Change 21(1):13-24

Nicholls N (2011) Comments on "Have disaster losses increased due to anthropogenic climate change?”. Bull Am Meteor Soc 92(6):791

Nordhaus WD (2010) The economics of hurricanes and implications of global warming. Clim Change Econ 1:1-20 
Pall P, Aina T, Stone DA, Stott PA, Nozawa T, Hilberts AGJ, Lohmann D, Allen MR (2011) Anthropogenic greenhouse gas contribution to flood risk in England and Wales in autumn 2000. Nature 470:382-385

Pérez-Morales A, Gil-Guirado S, Olcina-Cantos J (2018) Housing bubbles and the increase of flood exposure. Failures in flood risk management on the Spanish south-eastern coast (1975-2013). J Flood Risk Manag 11(S1):S302-S313

Pielke RA Jr, Landsea CW, Musulin RT, Downton M (1999) Evaluation of catastrophe models using a normalized historical record: why it is needed and how to do it. J Insur Regul 18(2):177-194

Pielke RA Jr, Rubiera J, Landsea C, Fernandez ML, Klein R (2003) Hurricane vulnerability in Latin America and the Caribbean: normalized damage and loss potentials. Nat Hazards Rev 4:101-114

Pielke AR Jr, Gratz J, Landsea CW, Collins D, Saunders M, Musulin R (2008) Normalized hurricane damages in the United States: 1900-2005. Nat Hazards Rev 9:29-42

Pielke RA Jr, Landsea CW (1998) Normalized hurricane damage in the United States: 1925-95. Weather Forecast 13:621-631

Preston BL (2013) Local path dependence of U.S. socioeconomic exposure to climate extremes and the vulnerability commitment. Glob Environ Change 23(4):719-732

Raghavan S, Rajesh S (2003) Trends in tropical cyclone impact: a study in Andhra Pradesh, India. Bull Am Meteor Soc 84:635-644

Sander J, Eichner JF, Faust E, Steuer M (2013) Rising variability in thunderstorm related U.S. losses as a reflection of changes in large-scale thunderstorm forcing. Weather Clim Soc 5:317-331

Schaller N, Kay AL, Lamb R, Massey NR, Van Oldenborgh GJ, Otto FL, Sparrow SN, Vautard R, Yiou P, Ashpole I, Bowery A, Crooks SM, Haustein K, Huntingford C, Ingram WJ, Jones RG, Legg T, Miller J, Skeggs J, Wallom D, Weisheimer A, Wilson S, Stott PA, Allen MA (2016) Human influence on climate in the 2014 southern England winter floods and their impacts. Nat Clim Change 6:627-634

Schinko T, Mechler R, Hochrainer-Stigler S (2018) The risk and policy space for loss and damage: integrating notions of distributive and compensatory justice with comprehensive climate risk management. In: Mechler R, Bouwer L, Schinko T, Surminski S, Linnerooth-Bayer J (eds) Loss and damage from climate change. Concepts, methods and policy options. Springer, Cham, pp $83-110$

Schmidt S, Kemfert C, Höppe P (2009) Tropical cyclone losses in the USA and the impact of climate change: a trend analysis based on data from a new approach to adjusting storm losses. Environ Impact Assess Rev 29:359-369

Serdeczny O (2018) Non-economic loss and damage and the Warsaw international mechanism. In: Mechler R, Bouwer L, Schinko T, Surminski S, Linnerooth-Bayer J (eds) Loss and damage from climate change. Concepts, methods and policy options. Springer, Cham, pp 205-220

Simmons KM, Sutter D, Pielke R (2013) Normalized tornado damage in the United States: 19502011. Environ Hazards 12(2):132-147

Strader SM, Ashley WS, Pingel TJ, Krmenec AJ (2017) Projected 21st Century changes in tornado exposure, risk and disaster potential. Climatic Change 141:301-313

Stucki P, Brönnimann S, Martius O, Welker C, Imhof M, Von Wattenwyl N, Philipp N (2014) A catalog of high-impact windstorms in Switzerland since 1859. Nat Hazards Earth Sys Sci 14:2867-2882

van der Geest K, de Sherbinin A, Kienberger S, Zommers Z, Sitati A, Roberts E, James R (2018) The impacts of climate change on ecosystem services and resulting losses and damages to people and society. In: Mechler R, Bouwer L, Schinko T, Surminski S, Linnerooth-Bayer J (eds) Loss and damage from climate change. Concepts, methods and policy options. Springer, Cham, pp 221-236

Visser H, Petersen AC, Ligtvoet W (2014) On the relation between weather-related disaster impacts, vulnerability and climate change. Clim Change 125(3-4):461-477

Visser H, Petersen A (2012) Inferences on weather extremes and weather-related disasters: a review of statistical methods. Clim Past 8(1):265-286 
Zhang Q, Wu L, Liu Q (2009) Tropical cyclone damages in China: 1983-2006. Bull Am Meteor Soc 90:489-495

Zhou Y, Li N, Wu W, Wu J, Gu X, Ji Z (2013) Exploring the characteristics of major natural disasters in China and their impacts during the past decades. Nat Hazards 69(1):829-843

Open Access This chapter is licensed under the terms of the Creative Commons Attribution 4.0 International License (http://creativecommons.org/licenses/by/4.0/), which permits use, sharing, adaptation, distribution and reproduction in any medium or format, as long as you give appropriate credit to the original author(s) and the source, provide a link to the Creative Commons license and indicate if changes were made.

The images or other third party material in this chapter are included in the chapter's Creative Commons license, unless indicated otherwise in a credit line to the material. If material is not included in the chapter's Creative Commons license and your intended use is not permitted by statutory regulation or exceeds the permitted use, you will need to obtain permission directly from the copyright holder. 